This item was submitted to Loughborough's Research Repository by the author.

Items in Figshare are protected by copyright, with all rights reserved, unless otherwise indicated.

\title{
Firearms licensing: facts in danger of neglect
}

PLEASE CITE THE PUBLISHED VERSION

PUBLISHER

(c) Perpetuity Press

LICENCE

CC BY-NC-ND 4.0

REPOSITORY RECORD

Pease, Catherine, and Ken Pease. 2019. "Firearms Licensing: Facts in Danger of Neglect". figshare. https://hdl.handle.net/2134/930. 


\title{
Firearms Licensing: Facts in Danger of Neglect
}

\author{
Catherine Pease and Ken Pease ${ }^{I}$
}

\begin{abstract}
The paper reports analysis of routine firearms statistics, whose importance is judged to have been neglected in the Cullen Inquiry ${ }^{2}$ into the disaster at Dunblane. It is shown that revocations and refusals of firearms licences and shotgun certificates rose after the Hungerford tragedy, fell thereafter, and only increased again after Dunblane. There was wide variation in the rate of revocation and refusal by police force area, which clearly stemmed from force practice rather than from the presenting situation. The predictability of regulation practice undertaken declines over time as staff and priorities change. Thus departmental stringency in regulation relative to other police forces will disappear over a period of 3-7 years. While the Firearms (Amendment) Act 1997 makes major changes in handgun availability, it makes only minor changes to firearms regulation, which remains the major protection against criminal use of the lethal weapons which are still legally held by citizens. Suggestions are made in the paper for making that regulation more stringent and more consistent.
\end{abstract}

\section{Key Words: Firearms; licensing; gun control}

\section{Introduction}

Thomas Hamilton entered Dunblane Primary School in South-West Scotland on 13 March 1996, and shot pupils and staff. Eighteen people died, seventeen of them small children. The carnage at Dunblane had many effects. Feelings of horror and rage were and remain pretty well universal. Many of us felt that if the bereaved parents wanted weapons of the kind that killed their children banned, then so be it. Only with hindsight does the complexity of the issue reassert itself in our minds. Whether changes in the legal availability of handguns stem from the facts of Dunblane or from sheer revulsion about the incident is open to question. How much such changes contribute to public safety, if at all, only time and adequate research may tell.

The purpose of this article is not to discuss changes in firearm availability consequent upon the events in Dunblane. Rather it is to point out that the process of granting, varying and revoking firearms licences remains substantially unchanged by the Firearms (Amendment) Act 1997. There will still be many thousands of lethal firearms in legal circulation. The regulation of the availability of the remaining weapons is still our primary safeguard. What can we learn from the basic statistics of regulation? Our obligation to the parents of Dunblane surely extends to the full analysis of such data in the hope of improving public safety.

As for the national relevance of the data, although the legislative framework in Scotland differs 


\section{Crime Prevention and Community Safety: An International Journal}

from that in England and Wales, in the case of firearm regulation the differences are not such as to limit generalisability. The recommended policy changes apply to England and Wales as much as to Scotland. We perceive the recommendations also to have applicability elsewhere, though more indirectly. In the month before we revised this paper, three separate gun incidents in the USA were reported in the UK media. Two of these resulted in the deaths of children and the third in the death of a teacher and the injury of children. Two of these incidents were school-based, although they differed from Dunblane in that the apparent perpetrators were children. It surely behoves us to take what lessons we can for gun control from the effect of each of these incidents on the routine regulation of weapons. This paper seeks to do this using data from Dunblane (and to a lesser extent earlier shootings in Hungerford, England). The wider implications of Dunblane are not limited to the United Kingdom, any more than the wider implications of the latest incident at Erie PA are limited to the USA.

Within eight days of the Dunblane massacre, Lord Cullen had been invited to head an inquiry into

\footnotetext{
...the circumstances leading up to and surrounding the events at Dunblane Primary School on Wednesday $13^{\text {th }}$ March 1996, which resulted in the deaths of 18 people; to consider the issues arising therefrom; to make such interim and final recommendations as may seem appropriate; and to report as soon as practicable. ${ }^{3}$
}

The Cullen Report ${ }^{4}$ is a wise and impressive document, particularly given the speed of its preparation (it was presented on 30 September) and the understandably febrile atmosphere of the time. It details the additional controls which could help prevent a recurrence of Dunblane, and is remarkably frank about the way in which the firearms lobby did itself a serious disservice:

\footnotetext{
... the umbrella body representing the interests of the shooting community at large were opposed in principle to any restriction on the availability of handguns, and objected not merely to the suggestion of one kind of ban or another but also ... to various measures stopping short of a ban. This entrenched attitude meant that as each measure was supposedly discredited what was at stake became the greater. That ... did mean that so long as the principle of there being any restriction was in dispute, there was no incentive for them to see how a measure less drastic than a ban could be made to work. ${ }^{5}$
}

In our view there are two shortcomings of the Cullen Report. First, it operated a double standard as between the police and the prosecuting authorities, both in terms of the evidence it demanded and the conclusions it reached from the evidence to hand, in both particulars to the disadvantage of the police. It would be possible to write an alternative report in which the prosecution system (in Scotland, Procurators-Fiscal) took the brunt of the criticism, particularly in creating a climate in which the police experienced major disincentives in revoking firearms licences. Second, the Cullen Report was sucked too much into broad criminological debate about gun ownership. It did not make best use of routine data. To the extent to which it dealt with criminological research, the report did so in relation to general matters such as the relationship between levels of legal gun ownership and levels of murder using firearms. While this is the traditional debate in criminology, it was arguably incidental to the particular circumstances of Dunblane Primary School. One instance of this concerns the merits of restricting the number of weapons which could be held on a single licence. Hamilton went into Dunblane Primary School with four handguns. In the event, he used only one. He had taken exceptional care to ensure that his weapons would not jam. The inference is that he wanted at least one usable weapon left with which to kill himself. The particular propensity of gun killers to commit suicide has been known for thirty-five years at least, ${ }^{6}$ and no doubt to experienced police officers for much longer. Had Hamilton been limited to fewer weapons, and thus increased the risk of being unable to kill himself, would he have acted as he did? The question thus posed 
may at least have led Lord Cullen to dwell longer on that control option.

Failures of the regulatory system were central to the Dunblane tragedy, but research on the regulatory system was absent from the report. In effect, the lead-up to Dunblane involved the repeated renewal of a firearms licence to a man who struck all those police officers who had contact with him before each one of those renewals as troubling and strange. These concerns were amply documented. Hamilton lied about his affiliations to gun clubs and shot excessively fast in competition, and 'talks about guns as though they were babies'. ${ }^{8}$ Five years before Dunblane, Detective Sergeant Hughes wrote a memo to his Detective Superintendent concluding:

I respectfully request that serious consideration is given to withdrawing this man's firearm certificate as a precautionary measure.

The sentiment was endorsed by DCI Holden:

... I do agree with DS Hughes' appraisal of Mr. Hamilton.

DCC McMurdo replied:

...I can not recommend the action proposed for obvious reasons, ie Hamilton has not been convicted of any crime. ${ }^{8}$

The Hughes, Holden and other reservations did not find their way into the appropriate file and the licence was renewed in 1992 and again in 1995.

DCC McMurdo faced criticism from Cullen and from the media. Our sentiment is that many other senior officers and prosecutors throughout the country must have felt that it was luck rather than good judgement that had spared them a similar fate. What is depicted by Cullen is a decision process wherein a view was taken, no doubt realistically, that the possibility of disaster was so remote as not to justify embarking upon a course of action which was problematic in its outcome, since the litigious $\mathrm{Mr}$ Hamilton would certainly have contested it. In brief, the balance of expected effort and advantage was against revoking Hamilton's licence. Firearms revocation, like much other crime prevention, is a thankless task in that by doing it well, evidence of success is precluded. If a potential killer is denied a firearm, the success of the revocation in saving life will never be known. What is necessary for the licensing system which failed in the months before Dunblane (and which remains substantially unchanged when applied to the weapons which remain) to succeed in the future? It is the awareness that marginal judgements must be settled in favour of revocation, in the certainty that such effort will be expended with much difficulty and no necessary expectation of success. What is required is a cast of mind which favours the expenditure of apparently unproductive work in the cause of public safety.

While criminological arcana were placed before Lord Cullen, routinely collected data lay unexamined. Indeed the neglect of how such data could inform debate is a recurring motif in crime policy. Such data can never provide conclusive answers to policy questions, but they can direct attention to important aspects of system operation.

\section{The data ${ }^{9}$}

Every year the Home Office publishes statistics of the number of firearms licences issued, revoked, varied and refused in England and Wales. It subdivides these into new applications for a licence and applications for renewal, and between shotgun certificates and firearms licences 
proper. In recent years, the number of weapons covered by licences issued has also been reported. All these data are divided by police force area and published as 'Firearms Certificate Statistics' as a Home Office Statistical Bulletin.

The first question which one can address using these data concerns trends over time in the number of licences revoked. Figure 1 shows the data. There are two distinct humps. The first, in 1988-9, can be linked to the aftermath of the Hungerford shootings which took place in August 1987. Consistent with such an interpretation is the fact that there was time between August and the end of 1987 for enough extra revocations to occur to make the beginning of the trend evident. The second, in 1996, can correspondingly be linked to the concerns after Dunblane, which occurred on 13 March 1996, ie in ample time to be reflected in the same year's figures. ${ }^{10}$ Equally obviously, 1996 revocations will not be affected by the provisions of the Firearms (Amendment) Act 1997.

Figure I. Number of firearms revocations $1987-96$

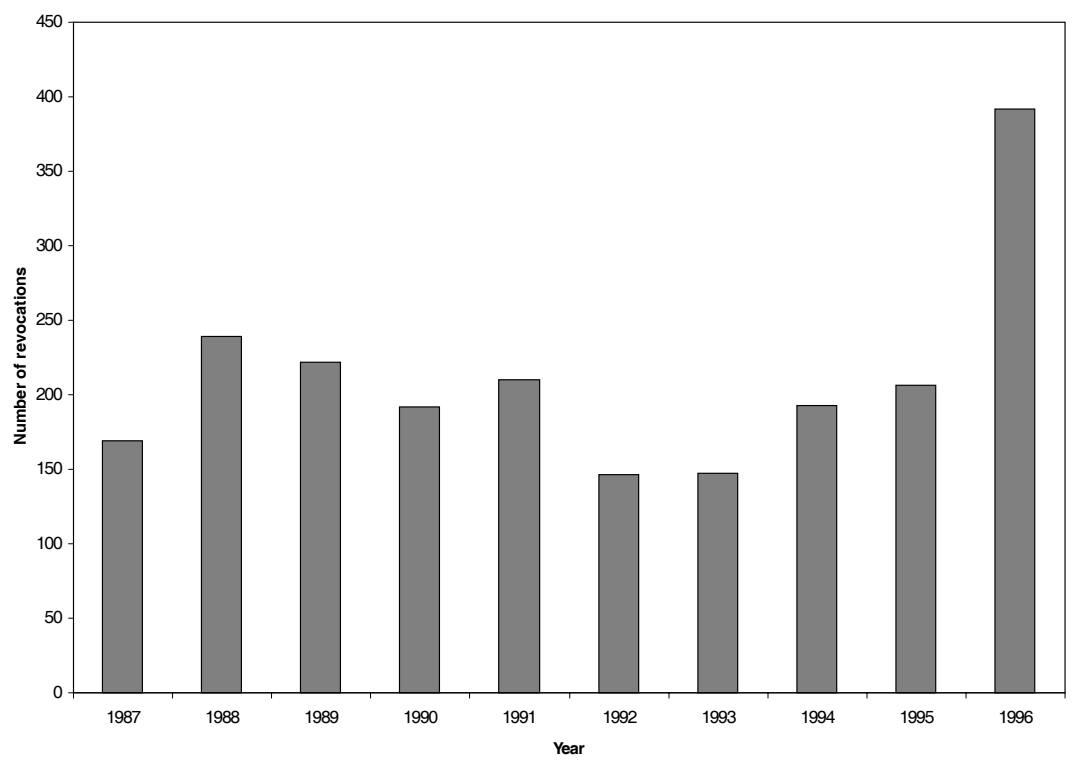

A similar pattern is observable in the rate of licences whose renewal or issue was refused, and this is depicted in Figure 2. It is of interest that the apparent effect of Hungerford was upon the renewal of licences, and of Dunblane (whose effect was much more modest) upon the issue of new licences.

A matter of no little interest is that the numbers (and rates) of refusal of firearms licences over the decade declined considerably. This means that the rise after Dunblane in Figures 1 and 2 is somewhat understated when considered against the total numbers of applications and licences issued.

How does the pattern for shotgun certificates vary over the same period? It will be seen from Figure 3 that the pattern is very similar to that for firearms, with two humps (Hungerford and Dunblane-induced respectively?) in the number of revocations.

Looking at the number of refusals of applications for new shotgun licences and their renewal, we turn to Figure 4. This tells a very similar story, with licence refusals increasing in the periods following the horrors. 
Crime Prevention and Community Safety: An International Journal

Figure 2. Refusal of grant or renewal of firearms licence

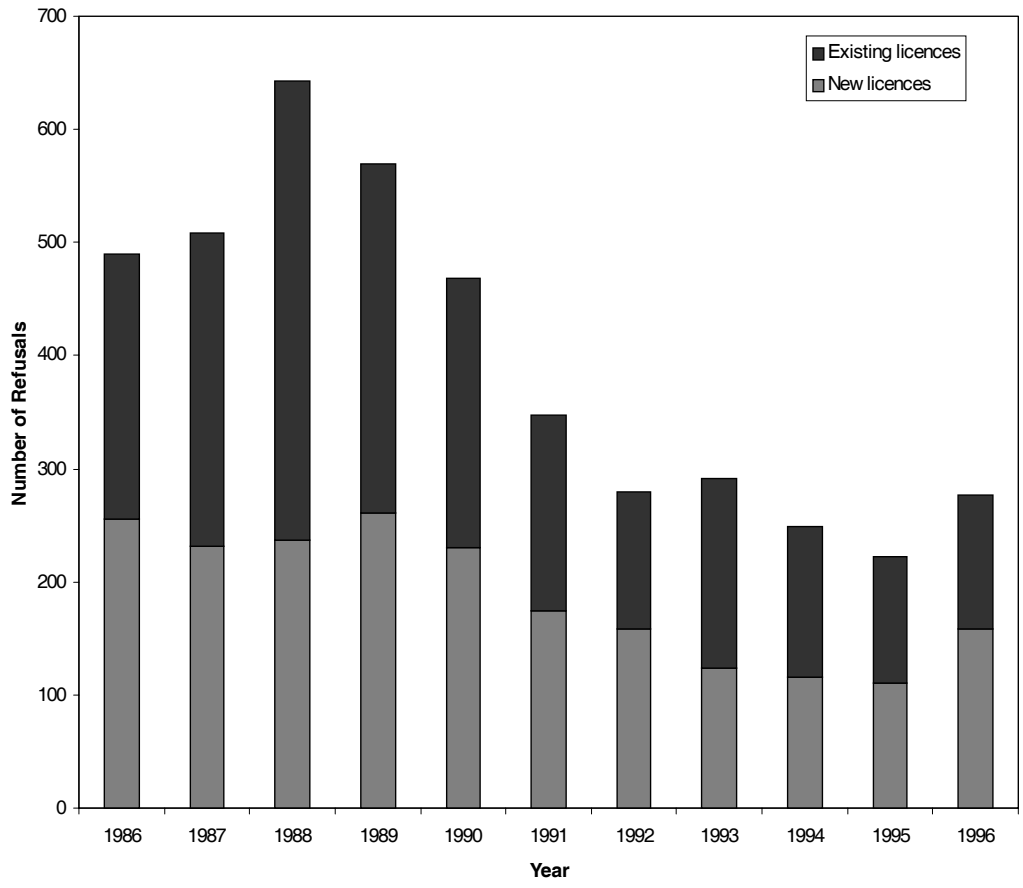

Figure 3. Shotgun licence revocations 1987-96

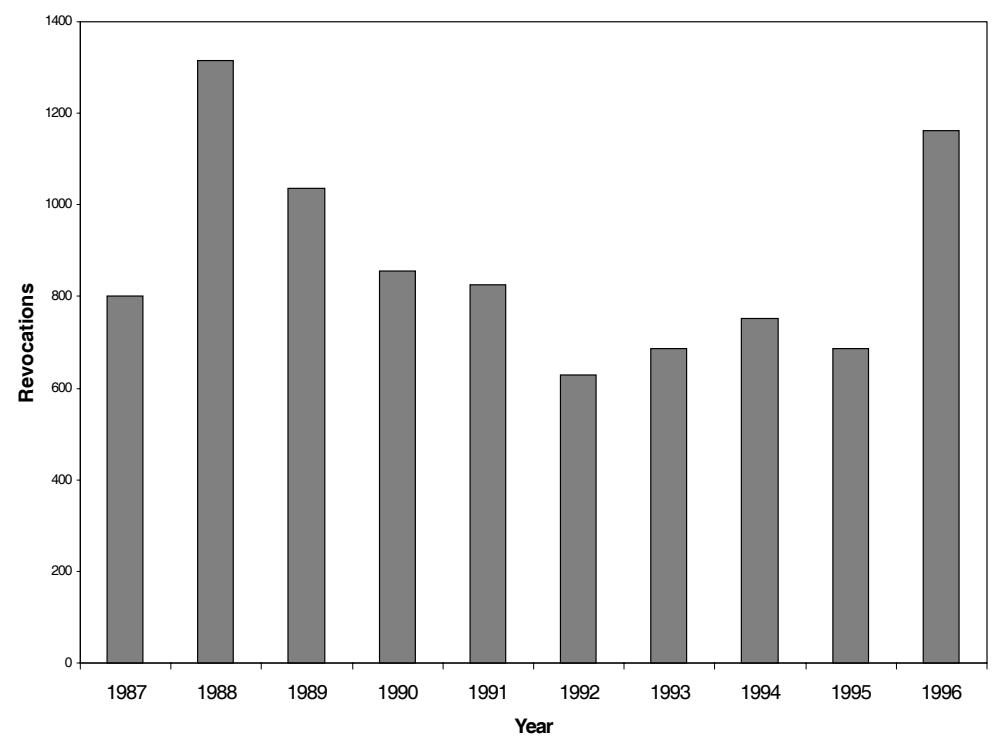


Figure 4. Refusal of new and renewed shotgun licences

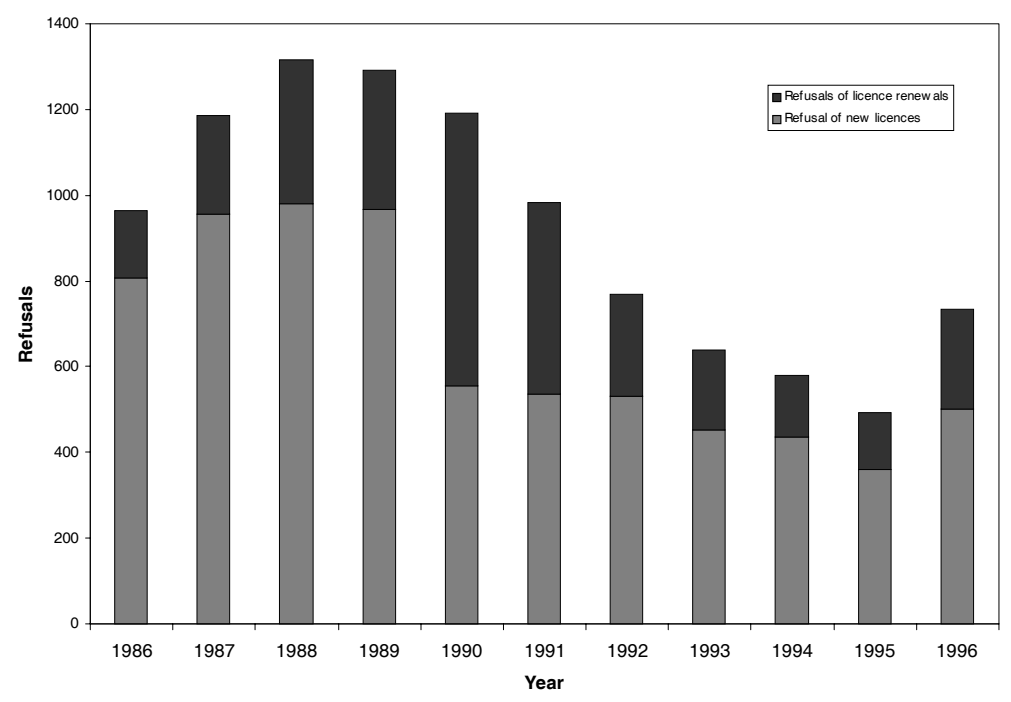

Our belief is that Hungerford and Dunblane focus the minds of police officers on the consequences of allowing people to hold guns who may conceivably use them to kill people. A long period with no cause célèbre and with other tasks presenting themselves on all sides will be accompanied by a reduction in the number and rate of licence refusals. This duly happened. As stressed earlier, this is in no sense a criticism of police practice, merely a recognition of the consequence of the invisibility of the success of timely revocation.

What else is predictable from the view that firearms control is sensitive to the social climate of the time? One prediction that is consistent with the foregoing is that of variation in revocation rates and other indices by police force area. One would expect a mindset which focuses on the dangers of issuing or renewing licences or allowing them to continue when they should be revoked to vary by police force area, depending on the experience of the officers concerned in firearms regulation, and the influence which they can bring to bear on senior officers. Certainly, rates of revocation are wildly variable by police force area, and in ways which do not lend themselves to interpretation in terms of area characteristics. Table 1 shows this for the rates of refusal of new and renewal applications for firearms licences and shotgun certificates respectively, using 1994 as a sample year.

Apart from stressing how low the rates of refusal and revocation generally are, Table 1 shows huge variation. For instance, nearly four per cent of new applications for firearms licences are refused in West Yorkshire. No such application was refused in thirteen forces. The differences are clearly not attributable to demography. Adjacent forces (such as Sussex and Kent, and the Yorkshire forces) often have contrasting levels of refusal and revocation.

These data, while variable, are not random, in that the rate of refusal or revocation for firearms is statistically associated with the equivalent rate for shotguns in the same year. Thus, for example, forces which tended to be high in rate of firearms licence revocation are also high in rate of shotgun certificate revocation in the same year. ${ }^{11}$

In short, police forces differ enormously in the rate of refusal or recommendation, and the same forces which are high in refusal for firearms are also high in refusal for shotguns. In a particular year, it is a matter of police force practice, which practice affects both categories of weapon. 
Table I. Refusals and revocations as a percentage of applications and licences on issue respectively (1994)

\begin{tabular}{|c|c|c|c|c|c|c|}
\hline FORCE & A & $\mathrm{B}$ & $\mathrm{C}$ & $\mathrm{D}$ & $\mathrm{E}$ & $\mathrm{F}$ \\
\hline Avon \& Somerset & 1.29 & .06 & .13 & 1.48 & .04 & .09 \\
\hline Bedfordshire & 2.46 & 2.25 & .07 & .59 & .09 & .07 \\
\hline Cambridgeshire & .00 & .60 & .14 & 1.31 & .08 & .18 \\
\hline Cheshire & 1.70 & .00 & .18 & 1.71 & .02 & .10 \\
\hline City of London & .00 & .00 & .00 & .00 & .00 & .00 \\
\hline Cleveland & .00 & .00 & .00 & .67 & .00 & .07 \\
\hline Cumbria & .26 & .00 & .06 & .84 & .00 & .03 \\
\hline Derbyshire & .00 & .00 & .21 & .43 & .03 & .16 \\
\hline Devon \& Cornwall & .47 & .29 & .08 & 1.53 & .03 & .08 \\
\hline Dorset & .40 & .13 & .11 & 1.54 & .00 & .04 \\
\hline Durham & .00 & .00 & .05 & 1.48 & .05 & .04 \\
\hline Dyfed-Powys & .00 & .00 & .12 & .22 & .00 & .05 \\
\hline Essex & .52 & .45 & .24 & 1.00 & .14 & .18 \\
\hline Gloucestershire & 1.06 & .00 & .00 & 1.01 & .00 & .06 \\
\hline Greater Manchester & .40 & .00 & .15 & 1.90 & .11 & .07 \\
\hline Gwent & .85 & .00 & .34 & .95 & .10 & .23 \\
\hline Hampshire & 3.10 & .85 & .07 & 1.72 & .19 & .09 \\
\hline Hertfordshire & .00 & .00 & .50 & .00 & .00 & .18 \\
\hline Humberside & .54 & .65 & .29 & 8.36 & .17 & .24 \\
\hline Kent & 1.51 & .95 & .05 & 2.23 & .12 & .09 \\
\hline Lancashire & .41 & .36 & .17 & 2.50 & .12 & .25 \\
\hline Leicestershire & .00 & .74 & .21 & .00 & .19 & .08 \\
\hline Lincolnshire & .84 & .00 & .12 & .52 & .02 & .09 \\
\hline Merseyside & 1.18 & .00 & .17 & .88 & .00 & .12 \\
\hline Metropolitan & 1.49 & .84 & .16 & 1.09 & .23 & .11 \\
\hline Norfolk & 1.85 & .51 & .22 & 2.23 & .10 & .14 \\
\hline North Wales & 2.67 & .34 & .33 & 3.28 & .07 & .17 \\
\hline North Yorkshire & .27 & .00 & .05 & .83 & .03 & .04 \\
\hline Northamptonshire & .00 & .17 & .22 & .00 & .11 & .14 \\
\hline Northumbria & .38 & .00 & .05 & 1.52 & .07 & .10 \\
\hline Nottinghamshire & 1.46 & .00 & .15 & 3.81 & .07 & .09 \\
\hline South Wales & .45 & .18 & .04 & 1.59 & .03 & .07 \\
\hline South Yorkshire & .00 & .27 & .17 & 3.09 & .14 & .18 \\
\hline Staffordshire & .48 & .29 & .19 & 1.22 & .02 & .09 \\
\hline Suffolk & .00 & .11 & .00 & .79 & .00 & .04 \\
\hline Surrey & .50 & .29 & .11 & .20 & .11 & .12 \\
\hline Sussex & .00 & .00 & .02 & .00 & .00 & .02 \\
\hline Thames Valley & .77 & .34 & .27 & 1.26 & .15 & .20 \\
\hline Warwickshire & .65 & .00 & .00 & .44 & .09 & .03 \\
\hline West Mercia & 2.15 & .46 & .15 & .80 & .00 & .16 \\
\hline West Midlands & 1.02 & .30 & .33 & 1.79 & .00 & .26 \\
\hline West Yorkshire & 3.93 & 2.07 & .16 & 3.73 & .11 & .16 \\
\hline Wiltshire & .00 & .00 & .08 & .80 & .06 & .05 \\
\hline
\end{tabular}

A. Percentage of new applications for firearms licences refused.

B. Percentage of applications for renewal of firearms licences refused.

C. Revocations of firearms licences as a percentage of licences on issue at year end.

D. Percentage of new applications for shotgun certificates refused.

E. Percentage of applications for renewal of shotgun certificates refused.

F. Revocations of shotgun certificates as a percentage of certificates on issue at year end. 
The next stage in the analysis is to show over how long a period a force is distinctively severe or lenient in its regulatory style. Our belief is that a force will be exceptionally high or low for a period of perhaps three or four years, that being the average period over which a particular group of officers with the same officer in charge remain responsible for firearms control in a force. If a force has special features which make it problematic consistently, then the enforcement level of a force should remain consistently high or low over the whole period covered. How can this be assessed? Force levels of refusal/revocation in one year may be correlated with force levels of refusal/revocation in other years. Thus, for example, levels of refusal of new firearms licences in 1986 can be correlated with levels of refusal in 1987, in 1988, and so on up to 1996. Levels in 1987 can be correlated with levels from 1988 to 1996, and so on.

The key question is the period over which refusal or revocation levels are predictable. Our guess, as stated above, was 3-4 years. Figure 5 contains the data for the refusal of new firearms licences, refused renewals and revocation of licences. The vertical axis portrays mean correlation between years a given distance apart (represented on the horizontal axis). Thus, for the item on the horizontal axis indicating one year apart, the data point shows the mean of the correlation between force refusal levels in 1987 versus 1986, 1988 versus 1987, 1989 versus 1988, 1990 versus 1989 and so on to 1996 versus $1995 .{ }^{12}$ For the point on the horizontal axis indicating five years apart, the data point shows the mean of the correlation between refusal levels in 1991 versus 1986, 1992 versus 1987, 1993 versus 1988, 1994 versus 1989, 1995 versus 1990, and 1996 versus 1991.

\section{Figure 5. Correlation of firearms regulation by years intervening}

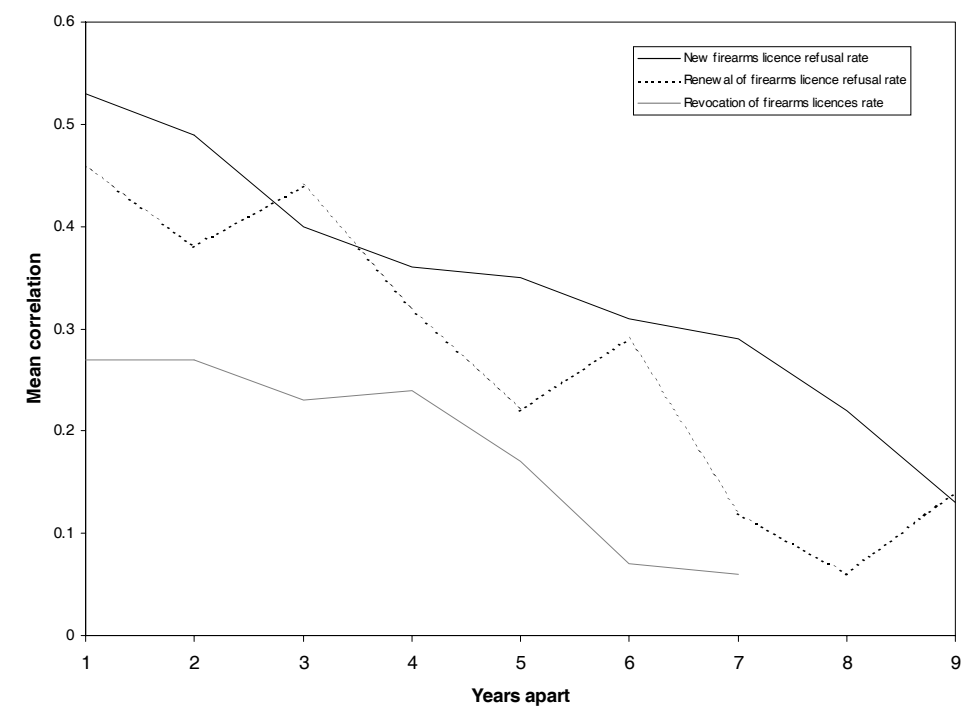

What Figure 5 shows is that force area practice in refusing new licences and licence renewals is predictable from year to year, but that predictability falls over time, so that after some seven or eight years, a force's practice relative to others bears little relation to its earlier practice. The decline is somewhat less precipitous than was anticipated, since we envisaged that it would take only 3-4 years before local practice became unpredictable from its history. However, the general principle stands, namely that force revocation practice becomes less predictable year to year. It takes only five years for revocation practice to change as much as refusal of licence applications do after eight years. 
Figure 6 is the equivalent of Figure 5, this time dealing with shotgun certification. It shows a similar pattern, but although area practice 'drifts' over time relative to other forces, it does so for the renewal of shotgun licences most swiftly, and for revocation least swiftly.

Figure 6. Correlation of shotgun regulation by years intervening

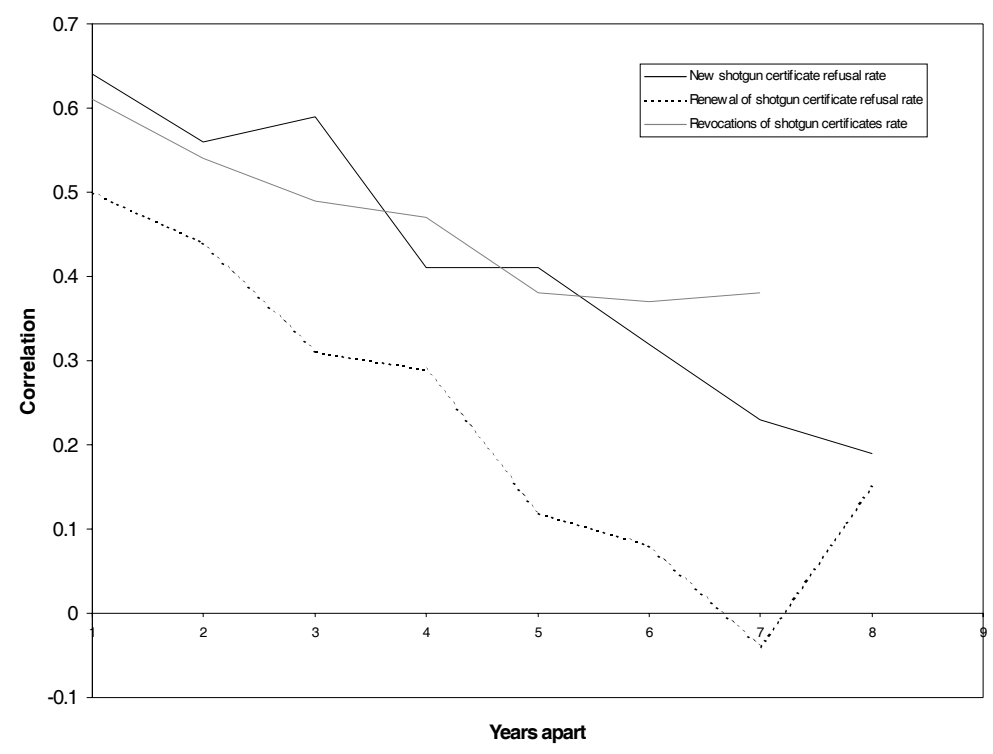

Looking at Figures 5 and 6 together, it is clear that the relative position of forces in regulation changes gradually over time, and declines most swiftly for the revocation of firearms licences. Why might this be so? We speculate that the revocation of firearms licences is the most proactive policing process in firearms regulation. These are weapons held primarily for sporting purposes. Revocation is an act instituted by the police. Police processing of applications for licences is reactive. Proactive policing may be thought most liable to major change over short periods of time, and depends upon the perspective of officers currently in post. In contrast, dealing with applications is to a greater degree an administrative process which can be robust over time in so far as procedures develop a life of their own.

One point whose absence might be a cause for comment is whether the changes remarked were greater in the area unfortunate enough to host the tragedy. We did not think this would happen, for two reasons. First, the tragedy would put such pressure on the relevant Department as to make 'business as usual' difficult enough to achieve, let alone greater rigour. Second, media coverage was such nationally that even the most distant police forces would be well aware of what had happened. However, we did a separate analysis which subdivided Thames Valley (the force which included Hungerford), those forces with a common boundary with Thames Valley, and the remainder of England and Wales. We did find that areas with a common boundary with Thames Valley showed the post-Hungerford bulge to a greater extent than did the remainder of the country. This suggests that the Hungerford events did have a particular impact in the same region, and serves to link the bulge still more closely to events at Hungerford. A similar analysis of the geography of the post-Dunblane bulge has not been undertaken, since Scottish data by police force area are not to hand. 


\section{Crime Prevention and Community Safety: An International Journal}

\section{Discussion and conclusions}

Showing a previous draft of this paper to a former head of a police Firearms Department elicited a lengthy comment in support of the argument advanced here. His reported experience merits quotation:

Most ACCs who responsibility for Firearms Departments are frightened to death of going to court to defend their decision. Instead of accepting that a (court) decision either way will give guidance for the future, they will grant or perhaps renew, with a caveat warning the Certificate Holder as to his future conduct. I was prepared to go to court as often as possible where I felt justified. There were some marginal cases but it was worth it. Remember too who is doing the background enquiries - PCs and Sergeants out on the ground, many have little idea or knowledge of firearms. They are under pressure, time is limited etc. Most do a good job, but some just do the minimum required. The result — a timebomb ticking away — we await the next incident.

Thomas Hamilton had his firearms licence renewed twice after behaving in ways, both in relation to his shooting and otherwise, which caused police officers who encountered him to worry about his stability. While the tragedy at Dunblane led to criticism of individual officers concerned, this is felt to be unfair. Any system whose successes (wise revocations/refusals) are hidden and whose failures (capricious revocations/refusals) are all too public will show certain characteristics. These, we believe, have been demonstrated in the foregoing in the Dunblane setting and are set out below, elevated to propositions.

1. Revocations, prohibitions and the like, when designed to prevent tragedy, will decline in their use as periods without tragedy become longer. Thus revocations/refusals rose after Hungerford, fell thereafter, and only increased again after Dunblane.

2. Effective regulation of human conduct which consumes time and effort and where disaster is rare will depend upon the imagination, experience and anxieties of those immediately involved. This will lead to wide variation in regulating units, as is the case with firearms legislation.

3. Depending on human priorities, the predictability of regulation practice undertaken by a particular unit will decline over time as staff and priorities change. Thus departmental stringency in regulation relative to other departments will disappear over a period of 37 years, depending upon the inertia of regulatory procedures.

These issues are not limited to firearms regulation. They form part of a raft of measures whose consequence can be termed 'the policing of lists'. Those on prison licence, those disqualified from driving, or on a sexual offenders register are all instances of people on lists. There now exists a plethora of lists in respect of which action must be taken, and in respect of which the failure to act becomes culpable when things go wrong later. The US experience of sexual offender registration ${ }^{13}$ gives no confidence that those lists in the USA are routinely used to advance human safety. Rather, finding a suspect's name on a list provides a convenient reason for detaining him or her in the absence of other justification.

Whenever policing lists, what is necessary to maintain standards over time is some immediate pay-off for rigorous action, as a countervailing pressure against the others, all of which conduce to inaction. In firearms regulation, for example, the ten per cent of forces exhibiting the lowest rate of licence revocation in the previous year could be invited by the Inspectorate of Constabulary to nominate their most problematic decisions not to revoke. These could be 
checked, and confirmed or otherwise. The attention drawn to being exceptionally low in revocations would itself be unwelcome, and the process undertaken would serve as a periodic check on the threshold set. Most crucially, it would serve as a disincentive to taking the line of least resistance by allowing a licence to run.

\section{Notes}

Catherine Pease is at the University of Sunderland and Ken Pease is at the University of Huddersfield.

Cullen, Hon Lord (1996) The Public Inquiry into the Shootings at Dunblane Primary School on $13^{\text {th }}$ March 1996. Cm 3386. Edinburgh: HMSO.

Ibid, piii.

Ibid.

Ibid, 9:110.

Gibson, E. and Klein, S. (1961) Murder. London: HMSO.

Cullen, op cit, 5:16.

Ibid, 6:41-42.

The data for this section is taken from: Home Office (1988) Statistics on the Operation of the Firearms Act 1968. Statistical Bulletin 2/88. London: Home Office; Home Office (1988) Statistics on the Operation of the Firearms Act 1968: England and Wales 1987. Statistical Bulletin 33/88. London: Home Office; Home Office (1989) Statistics on the Operation of the Firearms Act 1968: England and Wales 1988. Statistical Bulletin 18/89. London: Home Office; Home Office (1990) Statistics on the Operation of the Firearms Act 1968 to 1988: England and Wales 1989. Statistical Bulletin 26/90. London: Home Office; Home Office (1991) Statistics on the Operation of the Firearms Acts 1968 to 1988: England and Wales 1990. Statistical Bulletin 23/ 91. London: Home Office; Home Office (1992) Firearms Certificates Statistics: England and Wales 1991. Statistical Bulletin 19/92. London: Home Office; Home Office (1993) Firearms Certificates Statistics: England and Wales 1992. Statistical Bulletin 23/93. London: Home Office; Home Office (1994) Firearms Certificates Statistics: England and Wales 1993. Statistical Bulletin 22/94. London: Home Office; Home Office (1995) Firearms Certificates Statistics: England and Wales 1994. Statistical Bulletin 11/95. London: Home Office; Home Office (1996) Firearms Certificates Statistics: England and Wales 1995. Statistical Bulletin 11/96. London: Home Office; Home Office (1997) Firearms Certificates Statistics: England and Wales 1996. Statistical Bulletin 17/97. London: Home Office.

0 The pattern is not an artefact of changes in the number of licences on issue. The simplest mode of presentation is preferred throughout this article, to avoid suspicion of statistical 'smoke and mirrors'.

Nor is this a function of the dramatic change of a few areas. Thirty-three forces increased their number and rate of revocations. Unsurprisingly, the forces who changed most were those with the lowest rates of revocation in the pre-Dunblane year, $(\mathrm{p}<.01)$, in a possible recognition of their own relative vulnerability by dint of low revocation rates.

1 To a statistically reliable extent $(\mathrm{p}<.01)$ in each of the ten years for which revocation data exist.

2 Correlation varies between +1.00 , indicating a perfect relationship, through 0 , indicating no relationship, to -1.00 , indicating a perfect inverse relationship.

Hebenton, B. and Thomas, T. (1997) Keeping Track? Observations on Sex Offender Registers in the US. Crime Detection and Prevention Paper 83. London: Home Office. 